\section{B A Institute of \\ YK Business Administration \\ 六下 \\ Karachi \\ Leadership and Ideas for Tomorrow}

Business Review

Volume 6 Issue 2 July-December 2011

7-1-2011

\title{
Firm growth and industrial clusters: Implications for latecomer developing countries
}

\author{
Babur Wasim Arif \\ National Graduate Institute for Policy Studies (GRIPS), Tokyo, Japan \\ Sajid Manzoor Asadi \\ Asian Development Bank Institute (ADBI), Tokyo, Japan
}

Follow this and additional works at: https://ir.iba.edu.pk/businessreview

Part of the Growth and Development Commons

\section{(c) (1)}

This work is licensed under a Creative Commons Attribution 4.0 International License.

\section{Recommended Citation}

Arif, B. W., \& Asadi, S. M. (2011). Firm growth and industrial clusters: Implications for latecomer developing countries. Business Review, 6(2), 20-33. Retrieved from https://doi.org/10.54784/ 1990-6587.1191

This article is brought to you by iRepository for open access under the Creative Commons Attribution 4.0 License and is available at https://ir.iba.edu.pk/businessreview/vol6/iss2/3. For more information, please contact irepository@iba.edu.pk. 


\title{
ARTICLE
}

\section{Firm Growth And Industrial Clusters: Implications For Latecomer Developing Countries}

\author{
Babur Wasim Arif \\ National Graduate Institute for Policy Studies (GRIPS), Tokyo, Japan \\ Sajid Manzoor Asadi \\ Asian Development Bank Institute (ADBI), Tokyo, Japan
}

\begin{abstract}
In developing countries, traditionally micro and small scale enterprises have remained present since ancient times. Certain regions excelled in production of specific items.The industrial clusters have grown in these regions spontaneously in response to the grown competition.The cluster formation process was informal as the governments in developing countries have not played an adequate role for cluster formation and enterprises' networking.Due to absence of government leading role in clusters development, the majority of the industrial clusters in developing countries have not been able to enter from the initiation stage to the quality improvement stage with a very few exceptions. The upgradation of such stagnant clusters in developing countries could be instrumental in reducing poverty through employment generation. This paper draws the attention of the government to focus its industrial strategies on formation of industrial cluster and support their transition from initiation to quality improvement stage by proving appropriate training programs.
\end{abstract}

Keywords: Clusters formation, Firm growth, Human capital, Industrial development, Training,

JEL Classification: O10, O14, L60

\section{Introduction}

It has been increasingly recognized by policy makers and researchers that industrial development is indispensable for poverty reduction and to attain sustainable economic growth (e.g., David and Otsuka, 1994; Hayami et. al., 1998; Otsuka, 2006; Sonobe and Otsuka, 2006). Particularly, in developing economies, one policy that has attracted the growing attention of governments, private voluntary organizations, the donor community and researchers is the development of micro-, small-, and medium-sized enterprises (MSMEs) because they hold the potential of generating massive employment opportunities, dampening forced out-migration from rural to urban areas and bridging the development gap between the well-endowed and the marginalized (Bromley, 1978; Boomgrad et al. 1992; Mead, 1994; Mead and Liedholm, 1998).

In Pakistan, MSMEs (enterprises employing up to 99 persons) account for 90 
percent of total private business enterprises1. It is estimated that the share of these enterprises in non-agriculture employment is about 80 percent, while their contribution to GDP is less than 10 percent (Mustafa and Khan, 2005). The low share in GDP is due to the dominant presence of MSEs (enterprises employing up to 10 persons), which account for more than 95 percent of the MSMEs in the country. In Pakistan, like many other developing countries, although the number of micro- and small-sized enterprises has continued to grow, they have generally failed to survive or grow into medium- and large-sized enterprises (Kemal, A.R., 1993; B hutta, S.M., 2000).2 This is worrisome if Pakistan has to successfully reduce poverty through employment generation and promote industrialization that would enable her to join the league of the newly industrialized economies in Asia such as South Korea, Taiwan, Singapore, and China. The question that lingers in the minds of both policy makers and researchers is how effectively MSEs can be triggered to grow and sustain their growth.

By using the data from various industries, several studies have attempted to analyze the potential of MSEs growth in Pakistan (e.g. Kemal, A.R.1993; Ali and Sipra, 1998; Roomi and Hussain, 1998; Majid, et. al., 2000; Bhutta, M.S., 2000; ADB, 2005). In this study, we offer an alternative explanation that what is important is not whether MSEs have the potential to grow but under what conditions they can grow large in size.We discuss the importance of industrial clusters in overcoming the growth constraints confronting MSEs.The concept of industrial cluster had started attracting attention of policy makers and researchers in the early 1960s. The developing countries were far behind in adopting cluster formation and networking strategies, accordingly the concepts of clusters development emerged even later in their strategies. For instance, in Pakistan, though historically industrial clusters such as Sialkot's sports, and surgical instruments clusters, Sargodha's electrical fittings cluster, Faisalabad's textile and cotton ginning, Gujrat's wooden furniture, and Kasur's leather tanning were well known; cluster formation and enterprises' networking became the part of the national policy for industrial development in early 2000s (Dasanayaka, 2009).

While industrial clusters inherently contribute to the development of industries by creating economies of agglomeration, most of the industrial clusters in developing countries (in South Asia and Sub-Saharan Africa) have performed poorly relative to what appears to be their growth potentials. In search of what are the decisive factors that affect the dynamic development of a cluster, further in this paper, we discuss how an industrial cluster develops from initiation to quantity expansion phase, and further to quality improvement phase; and what factors are important for the transition of cluster from quantity expansion phase to quality improvement phase?Specifically, we present some experiences from East Asia and other developing countries to illustrate the process of successful cluster-based industrial development, placing particular emphasis on the importance of innovations in the development of industrial clusters.

The rest of this paper is organized as follows.Section 2 reviews the theories of firm growth. Section 3 discusses why enterprises form clusters, why clusters are desirable, and how clusters facilitate enterprise growth. In Section 4, some experiences from East Asia and other developing countries are drawn to illustrate the process of successful industrial development, placing particular emphasis on the importance of innovations in the development of industrial clusters followed by conclusion and policy implications contained in Section 5 .

\section{Theories of firm growth}

Theories of firm growth are still in their infancy.No concrete and robust theory 
that fits various situations has been developed so far to explain the determinants of firm growth.Although, the determinants of firm growth still remain an enigma, researchers are still determined to unravel it.Efforts to develop an appropriate theory of firm growth began after the pioneering work of Robert Gibrat in the 1930s. In his work, Gibrat explored the impact of firm size on the expected growth of the firm.He found that there is no relationship between the size of the firm and the firm growth. Small and large firms have equal probabilities of attaining a particular growth rate within any given time period.The empirical regularity suggested by Gibrat that "the expected growth rate for a firm is independent of its size" later became well known Gibrat's law (Eatwell, Milgate and Newman, 1987). This law served as a point of ignition for debates among economists interested in firm growth, both the believers and non believers of Gibrat's law.

Lotti, Santarelli, and Vivarelli (1999) found mixed evidence for Gibrat's law in some selected manufacturing industries in Italy.In the early years after start-up, the small firms grow at a higher rate as compared to the large firms. However, in the long run, both small and large firms exhibit more or less similar growth rates, suggesting convergence towards the pattern of growth predicted by Gibrat's law.Hence Lotti, Santarelli, and Vivarelli (1999) argued that the validity of Gibrat's law depends on the life cycle of the enterprises.Hall (1987) observed a similar pattern in US manufacturing industries.

On the other hand, McPherson (1996) contended that firm growth is inversely related to firm age and firm size in four Southern African countries out of five that he studied. That is smaller and younger firms grow more rapidly than older and larger firms. This finding represents evidence against Gibrat's law. In the industries that exhibited an inverse relationship between growth and size, and growth and age, other factors also have a significant impact on firm growth. These factors include the level of human capital represented by the schooling of the firm's manager, the firm's location, the sector to which the firm belongs, and the even proprietor's gender. Evans (1987) also found an inverse relationship between firm growth and firm size, and firm age. In contrast, Pagano and Schivardi (2000) demonstrated that the firm size is positively correlated with growth in terms of the value added per worker. It is therefore clear from various empirical studies that Gibrat's law has often failed to explain firm growth.

Unlike the other studies that have been static, Jovanovic (1982) suggested a dynamic model of firm growth. The Jovanovic (1982) model of firm growth is based on the assumption that all firms produce homogenous products and face the same factor prices, and that there are two types of costs. The first is an immutable cost determined by the managerial ability of the firm's proprietor. If the proprietor possesses a very low managerial ability, the firm tends to incur high cost. The second is the production costs affected by random factors. Normally, the firms are unable to predict the true size of these two costs in each period. However, the potential firms know the distribution of the true costs. The "learning" model of Jovanovic (1982) explains that during the process of learning in which a firm's cumulative output increases over time, a firm continues to draw various costs and us es them to update the estimates of its true managerial ability. The firm then decides to stay in or exit the industry after having a comparison of its expected profits with the opportunity cost of the capital invested. If in a particular time period the updated estimates of one's managerial ability indicate that the expected profits will be less than the return to capital from the best alternative, the firm will exit the industry being less efficient than those who stay in the industry. Similarly, if the true cost is low, it is likely that acquired updated information will be favorable, and the firm will survive and grow. Thus, the learning model of Jovanovic 
(1982) suggests that the inefficient firms tend to decline or exit the industry while efficient firms survive and grow with time. This occurs due to the selection process in which one's estimated true managerial ability is based on past production experience. This is consistent with the neoclassical theory of the firm, which predicts that in a competitive market, the firm declines if the average cost exceed the price and survives if the cost is lower than the price. The new firms that are attracted by the profit enter into the industry and the inefficient ones exit. In the long run, however, the industry reaches a stage where there are no more incentives for any firm to enter or exit the industry.

The Jovanovic model may be relevant to new industries that face large uncertainties in production and management. Many entrepreneurs with even low skills can easily initiate new enterprises since the technology used in the production tends to be simple to operate and the capital requirement is low.The growth of these enterprises, however, will depend on the management capability of their proprietors. If there are many proprietors who fail to recognize that their managerial capabilities are insufficient to manage the enterprises, we tend to observe that many small enterprises which enter the industry either leave or do not grow at all. In this way, Jovanovic's model may provide an insight into firm growth dynamics in the early stage of industrial development.A major drawback of Jovanovic's model is that it assumes that there is no technological change.In reality, through learning by doing and through innovation and imitation, the firm's manager and workers tends to absorb new technological information which shifts the firm's marginal and average cost curves downward over time.

Bahk and Gort (1993) take "learning by doing" as an accumulation of knowledge and skills without any additional cost to the firm being a by-product of the normal production process of goods and services3. Irwin and Klenow (1994) found, in their study of semiconductor industries in the U.S. and Japan, that firms learn three times more from an additional unit of their own cumulative production than from an additional unit of another firm's cumulative production. Since over time a firm learns from its own production process as well as from other firms, the young firms may tend to grow faster than large firms as the former would be in a better position to devise an effective strategy for cost reduction and quality improvement.

Factors such as innovation and imitation cause a reduction in production cos ts. Various models have been constructed to explain innovation and learning by doing. For instance, Young (1993) argued that firms learn through innovation and in the early stage of industrial development, when the cost of innovation is small, innovation would be extremely profitable. Sonobe et al. (2003) argued that only few firms innovate from whom many other firms imitate and grow in size and expand their production. However, those firms that are run by incapable managers who fail to innovate or imitate will face difficulty in growing. For instance, cottage industries that did not participate in the innovation process in rural Indonesia continued to produce traditional hand-molded tiles and did not grow, while those that adopted innovations (metal casing and textile weaving industries) grew more rapidly and earned profit (Weijland, 1999). In addition to the manager's inborn capability, the educational level of the manager reinforces his ability to learn by doing and innovate, and hence serves as a driving force to the firm growth. Since the supply of capable and knowledgeable managers is limited in developing countries, a limited number of firms are expected to grow, while others are expected to stagnate or exit from the industry.

According to the latest Economic Census of Pakistan (2005), industry structure 
of Pakistan is dominated by a large number of MSEs, while there are few medium-, and large-sized enterprise. This may be explained by the continuous influx of new enterprises that face low entry barriers. Since most of the new enterprises may have managers with low ability to innovate or imitate, or even to learn by doing, small firms tend to have low optimal size and many of them may either not grow, or exit when market competition strengthens. On other hand, new and small firms with capable managers will grow and become larger over time. If there is no major innovation, as in the dynamic model of Jovanovic (1982), the contribution of MSEs to growth in GDP may be mainly due to an overall increase in the labor and physical capital inputs associated with the entry of new firms. Indeed, consistent with the prediction of the Jovanovic model, there are few mediumsized enterprises in Pakistan since the majority of the MSEs do not grow (Kemal, A.R., 1993; Buttha, S.M. 2000). In rest of this article we explain how an industrial cluster facilitates firm's growth, and what factors are important to maintain the dynamism in the cluster for its long-term survival, sustainability, and growth.

\section{Industrial clusters and firm growth}

\section{Definition of an industrial cluster}

There is a variety of different concepts and definitions of industrial clusters in the literature having roots in business economics, innovation studies and development economics. For example, Porter (1990) defined a cluster as a geographic concentration of interconnected companies and institutions in a particular field. Rosenfeld (1995) defined a cluster as a loose, geographically bounded agglomeration of similar, related firms. Similarly, Swann and Prevezer (1996) defined an industrial cluster as a group of firms within one industry based in one geographic area. Schmitz and Nadvi (1999) defined a cluster as a sectoral and spatial concentration of firms. Brenner (2004) also defined a local industrial cluster as an industrial agglomeration that is caused by local self-augmenting processes. Piero (2004) defined an industrial cluster as a socioeconomic entity characterized by a social community of people and economic agents localized in close proximity in a specific geographic region. Sonobe and Otsuka (2006) defined an industrial cluster as a geographical concentration or localization of enterprises producing similar or closely related goods in a small area.

There are few points worth noting in the above definitions of an industrial cluster. First, is the importance of the spatial proximity and geographic scope of the cluster which greatly facilitates the flow of crucial business related information central to the capability to innovate. Second, a cluster is a dynamic phenomenon. It is not only the localized concentration of linked industries but the particular process that leads to the development of the interaction and functional relationships between firms. Last, social infrastructure such as trust and a shared vision is important.

\section{Significance of industrial clusters}

Industrial clusters, in the last two decades, have gained considerable attention from economists and researchers because of their contribution to employment generation, poverty alleviation and provision of a favorable environment for further industrial development by creating economies of agglomeration (e.g., Krugman, 1991; Nadvi and Schimtz, 1994; Hayami, 1998; Schimtz and Nadvi, 1999; Sonobe and Otsuka, 2006). Agglomeration economies, which lead to economies of scale at the level of an industry rather than at the level of an individual enterprise, induce enterprises to locate close to each other (Schmitz 
and Nadvi, 1999; Henderson, Shalizi and Venables, 2001). According to Marshall (1920), the agglomeration economies arise from 1) knowledge and technology spillovers; 2) specialization and division of labor among enterprises; and 3) labor pooling.

Knowledge and technology spillovers refer to technological external economies that arise when new ideas on new products, inputs, production processes and marketing channels of innovative enterprises become available to other enterprises without any compensation. The knowledge and technology spillovers take place through sheer imitation of products and production processes, turnover of workers, spin-offs, and face to face interactions. According to Porter (1998), the diffusion of technological knowledge enhances enterprises' capacity for innovation and competitive pressure within each cluster increases enterprises' incentive to innovate. According to the endogenous growth models of Lucas (1988, 1993) and Romer (1986, 1989), knowledge spillover is critical for sustainable economic growth. The empirical literature has proven that knowledge spillovers tend to be localized (Jafe et al., 1993; Feldman, 1994). Thus, enterprises located in an industrial cluster take more benefit of knowledge spillovers than dispersed enterprises.

The second benefit of industrial clusters, identified by Marshall (1920), is the specialization and division of labor among enterprises. Suppliers of specialized inputs and services emerge in industrial clusters since the demand from a large number of co-located enterprises is large. The availability of such specialized inputs and services, in turn, enables new enterprises to enter the industry by specializing in a particular stage of production without much initial capital investment (Schmitz and Musyck, 1994; Humphrey and Schmitz, 1996; Schmitz and Nadvi, 1999). To put in a different way, industrial clusters permit new enterprises to take small and calculable risks to enter the industry or they enable small enterprises to overcome growth constraints and to develop in small "riskable steps" (Schmitz and Nadvi, 1999).

Most of the literature on economic geography (e.g., Krugman, 1991) often points out that specialization and division of labor among enterprises occurs because of low transportation costs owing to the geographical concentration of firms in a small area. However, Sonobe and Otsuka (2006) argue that low transaction costs among enterprises rather than transportation costs in industrial clusters enhance the development of the division of labor and facilitate the transactions of intermediate goods and services among enterprises. According to Sonobe and Otsuka (2006), in a cluster it will be immediately noticed if some firms attempt to overutilize as ymmetric information, or pass substandard goods as premium grade, or create hold-ups in order to exploit market shortages. Behavior of this kind puts firms on a black list which deprives them from information and trading opportunities. Through this sanction mechanism, firms in an industrial cluster create a mutual understanding and trust that reduces malfeasance and facilitates trade. Sonobe and Otsuka (2006) particularly emphasize the importance of the division of labor between producers and traders. The scarcity of market information, which is one of the major bottlenecks on small firm growth, can be reduced in a cluster through traders. Clusters attract traders because they have a wider choice of producers and products to choose from. Furthermore, the cost of searching and negotiating between traders and producers tends to be low in clusters because of the concentration and competition of a large number of producers in a small area (e.g., Levy, 1991; Sonobe, Hu and Otsuka, 2002, 2004; Yamamura, Sonobe and Otsuka, 2003).

The third advantage of industrial clusters identified by Marshall (1920) in addition to knowledge spillovers and the specialization and division of labor among enterprises is 
labor pooling. Labor pooling refers to the presence of a labor force with specific skills suitable for the particular industry in the cluster. Industrial clusters attract skilled workers and managers because the demand for skills specific to industry is large due to the colocation of a large number of enterprises. This means that new enterprises entering the cluster can easily employ skilled workers, as the transaction costs involved in the search for the desired quality of workers are low. New enterprises are also likely to enjoy relatively low wages as competition among skilled workers is likely to prevent a monopoly from arising and thus help to keep wages at low levels (Glaeser et al., 1992).

According to Sonobe and Otsuka (2006), information spillovers which are essentially imitations are closely related with the development of skilled labor markets. The latter enhances the former through spin-offs and labor turnover. Since imitation also takes place through transactions of intermediate inputs, information spillovers are also inseparably related with the specialization and division of labor.

Firms that are clustered may also become involved in joint actions, in which they may share machinery, agree to split an order, share the costs of marketing, lobby government, and participate in other collective activities. The benefits that are generated through these collective actions are referred to as "collective efficiencies" (Schmitz, 1995b; Nadvi, 1999a), which are defined as "the competitive advantages derived from the local economies and joint actions".

Industrial clusters have played a crucial role in the economy of Japan during the high growth period from 1960 to 1973 (Mano and Otsuka, 2000). Other economies such as Taiwan (Amsden, 1977; Sonobe and Otsuka, 2006), China (Sonobe, Hu and Otsuka, 2002), India (Knorringa, 1999; Tewari, 1999; Chari, 2000), Brazil (Meyer-Steamer, 1998; Schmitz, 1999b), and Mexico (Rabelloti, 1995, 1997, 1999) have also registered significant and rapid cluster-led economic growth. In Taiwan, small enterprises were induced to form clusters in suburban areas to capture the benefits of inert-firm transactions (Sonobe and Otsuka, 2006), while in the Philippines, low transaction costs arising from the benefits of agglomeration enabled subcontractors located in garment and metal craft clusters to earn relatively high incomes (Sonobe and Briones, 2001). In rural Indonesia, the development of social capital reduced transaction costs, which attracted traders to the clustered enterprises. Thus, the cottage industry in rural Indonesia owes its success to the importance of clustering at the early stages of development: accessibility to credit that was once a big problem for MSEs was eased due to the proliferation of formal and informal credit sources, innovations and imitation were common, and so was the sharing of orders and subcontracting, while the division of labor was also practiced by successful firms. This provided the clusters with stimuli to expand (Weijland, 1999).

Despite the benefits of industrial clusters, many industrial clusters in developing countries (in South Asia and Sub-Saharan Africa) have performed poorly relative to what appear to be their development potential (e.g., McCormic, 1999; Altemburg and MeyerStamer, 1999). This raises a question as to why some clusters have developed dynamically while many others stagnate. In search of what is important in the successful development of industrial clusters, in the following section, we draw some experience of successful cluster-based industrial development from East Asia and other developing countries. 


\section{Process of industrial development in clusters}

There are empirical studies on East Asia which suggest a common pattern of industrial development in the region (e.g. Sonobe and Otsuka, 2006). This pattern my offer useful lessons for developing countries, in particular, for Pakistan on its path for sustainable industrial development. In what follows, we discuss the Sonobe-Otsuka (2006) model of industrial development to gain an understanding of the dynamic process of industrial development. Based on eight case studies on the garment, motorcycle, machine tools, and low-voltage electric appliances clusters in East Asia, the Sonobe and Otsuka (2006) identified at least three phases of industrial development namely: the initiation phase, quantity expansion phase, and quality improvement phase.

According to this model, once technology is simplified and standardized in the initiation phase, a massive entry to the industry takes place which increases the supply of products so rapidly that output prices decrease and input prices increase, thereby reducing the profitability in the quantity expansion phase. The declining profitability in turn triggers new competition centered on the improvement of the product quality, the establishment of brand names, and the development of new marketing channels in the quality improvement phase. Such innovations become possible because of the availability of diverse human resources such as skilled workers, engineers, merchants, and part suppliers. In what follows, this model describes the evolutionary process of the formation of industries from the initiation phase through to the quality improvement phase.

In this model, pioneers of new industries include those who have acquired foreign technology by working in foreign ventures, conducted reverse engineering of imported products, or copied technology already introduced elsewhere. If the products are technically easy to produce, the industrialization tends to be led by merchants, and if the products are technically difficult to produce, the development is often engineer-led. For example, in analyzing the development process of the garment industry in postwar Japan, Yamamura et al. (2003) indicate that local traders who possess the relevant marketing knowledge played a leading role in launching the new business of garment production in a small town. The initiation phase is characterized by a great deal of trail and error since there is limited availability of the required parts, material, and workers in the domestic market. The market for parts and components is not yet present and the quality of the final products is generally low, but owing to the low income level of the economy, there exists a demand for such lowquality but cheap substitutes for expensive imported products.

After the successful initiation of the cluster, a number of workers who have learnt the established production and marketing methods of the pioneer enterprises, spin-off and establish their own enterprises. They are the followers in the sense of Schumpeter (1912) and they produce the same or similar products using the same or similar parts and equipment. The cost of market transaction at this stage is low since both final products and parts are simple and similar. The division and specialization of labor develop between manufacturers and part-suppliers and between manufacturers and traders, with transaction usually undertaken through impersonal markets. New enterprises are located near each other and industrial clusters are ultimately formed. As Marshall (1920) noted, enterprises located in industrial clusters easily imitate new technology developed by other enterprises, purchase (or sell) parts and intermediates products from (or to) other enterprises, and hire workers with the required skills, because industrial clusters facilitate the acquisition of inputs, technology, and market information at relatively low transaction costs. The availability of intermediate 
inputs at the market place and traders who handle the marketing of the simple and standard products massively attracts new entrants who produce the low quality standard goods. Sonobe and Otsuka (2006) refer to this phase as the quantity expansion phase because production expands with negligible productivity gains and quality improvement.

The quantity expansion phase is characterized by declining product prices and a rise in material prices as a result of the expansion of production due to the massive entry which outweighs product demand. The decrease in product price might discourage the innovative efforts of producers. Fortunately, innovation cost is also reduced as a variety of skilled human resources such as engineers, designers, experienced workers, merchants, and specific part suppliers gather in one place during the formation of the industrial cluster and provide opportunity for innovative producers to adopt innovations ranging from finding new sources of input to exploring new marketing channels. Producing high quality differentiated products requires the use of high quality materials and employing highly skilled workers. To appropriate the benefit of producing high quality products, producers need to use new marketing channels to reach final buyers in order to differentiate high quality products from imitated standardized products in the market. Such successful "multifaceted innovations" lead the cluster to enter the quality improvement phase ${ }^{4}$.

Examples of such multifaceted innovations can be found in the literature. For example, in the case of the low voltage electric appliances cluster in China, the major innovations involved the introduction of quality inspection and own branding (Sonobe et al., 2004). Enterprises in a footwear cluster in Ethiopia increased the direct procurement of materials and the direct sales of products as well as established brand names when they improved product quality (Sonobe et al., 2009). In Italy and Brazil, when the pressure of competition increased, shoe manufacturers turned to the long-term subcontracting system by finding competent part-suppliers (Rabellotti, 1995; Schmitz, 1999b). In contrast, when specific and complicated parts were required, enterprises increased the internal production of key parts to improve quality as in the case of surgical instrument manufacturers in Pakistan (Nadvi, 1999a).

A major characteristic of the quality improvement phase is that the productivity of the industry as a whole rises sharply partly because of the exit of inefficient enterprises and partly because the surviving enterprises improve products and production processes. Another characteristic is the reemergence of large enterprises that produce and sell high quality products with brand names through networks of their sales agencies and own retail outlets. Sonobe and Otsuka (2006) hypothesize that enterprise managers cannot innovate if high-quality human resources are lacking, because in absence of human capital resources the cost of innovation is too high. Thus, the industrial cluster enlarges opportunities to innovate, because it attracts a variety of human resources.

Sonobe and Otsuka (2006) also investigated the characteristics of the innovative entrepreneurs. In all of the eight clusters they studied, they found that generally highly educated entrepreneurs led the industries to the quality improvement phase by taking the initiatives in improving the product quality, production organization, and marketing channels. As a result, these entrepreneurs tend to have larger operation size and higher productivity. It is important to mention that in industrial clusters in other developing countries in Asia and Africa, there is a striking similarity in the important roles of the entrepreneur's general human capital (Sonobe et al., 2002, 2003, 2004, 2009; Yamamura et al., 2003, 2005; Akoten, 
et al., 2006; Akoten and Otsuka, 2007; Nam et al., 2009, 2010). In addition to formal education, the entrepreneurs' skills and management abilities, which improved through learning by doing during the quantity expansion stage, facilitate the transition to the quality improvement stage. For instance, in the motorcycle clusters in Japan, the entrepreneurs' work experience found to be important for multifaceted innovations (Yamamura et al., 2005). In the printed circuit board clusters in China and in Taiwan, the entrepreneurs' knowledge from their work experience has continual positive effects on the choice of product lines, the product quality, and the growth of the enterprises (Sonobe et al., 2004, 2006). In the garment clusters in China and in Japan, the entrepreneurs' prior experience in marketing contributed to the improvement in the quality of products, the increase in the direct transaction with outside traders and the productivity of the enterprise (Sonobe et al., 2002; Yamamura et al., 2003). These findings suggest that the entrepreneurs' industryspecific and firm-specific human capital acquired by experience in marketing and management also enhances their ability to innovate and so the transition of cluster from quantity expansion to quality improvement phase.

\section{Conclusion}

Although effective policies to promote the development of micro-, small-, and medium-sized enterprises (MSMEs) have been seriously sought in many developing countries, economic theories that can guide such policy have been absent. The literature on industrial development suggests that the market works fairly well in industrial clusters because dishonest behaviors potentially arising from imperfect information are reduced to a significant extent by the informal contract enforcement mechanisms. Industrial clusters provide the synergy through which micro- and small-sized enterprises (MSEs), which provide ample employment opportunities for unskilled workers, may grow particularly in their early phases of development. This provides good reasons for the government to support the formation of industrial clusters. However, the governments in developing countries including Pakistan have played an inadequate role to promote industrial clusters and MSEs networking. The governments remained devoted in promoting large multinational or local enterprises due to which the prospective benefits of MSEs have remained unexplored. The governments can play a leading role by setting up model plants to train potential managers and workers, industrial zones to attract MSEs producing similar and related products, and marketplaces to facilitate transactions of parts, intermediate products, and final products among manufacturers and merchants.

To propel the further development of industrial clusters, the appropriate educational and training programs to support their transition from the quantity expansion phase to the quality improvement phase must be provided. Particularly, training programs that equip the entrepreneurs with new knowledge on management, such as quality control, labor management, production organization, and new knowledge on marketing, should be provided. Because the provision of such knowledge has spillover effects and is often undersupplied by the private sector, government agencies, international organizations, and NGOs should provide these training programs to the entrepreneurs.

\section{Refrences}

Akoten, J. E., and Otsuka, K. (2007) "From Tailors to Mini Manufacturers: The Role of Traders in the Performance of Garment Enterprises in Kenya," Journal of African Economics, 16(4), 564-595. 
Akoten, J. E., Sawada, Y., and Otsuka, K. (2006) "The Determinants of Credit Access and Its Impacts on Micro and Small Enterprises: The Case of Garment Producers in Kenya," Economic Development and Cultural Change, 54(4), 927-944.

Ali, S. M., and Sipra, N. (1998) "The Financial Practices of Small and Medium Enterprises in Pakistan," Konrad Adenauer Foundation Working Papers Series. Lahore University of Management Sciences (LUMS), Lahore.

Alternburg, W., and Mayer-Stamer, J. (1999) "How to Promote Clusters: Policy Experience from Latin America,” World Development, 27(9), 1693-1713.

Amsden, A. A. (1977) "The Division of Labor is Limited by the Type of Market: The Case of the Taiw anese Machine Tool Industry," World Development, 5(3), 217-233.

Asian Development Bank, ADB (2005) "SME Development in Pakistan: Analyzing the Constraints to Growth,” ADB, Islamabad.

Bahk, B. H., and Gort, M. (1993) "Decomposing Learning by Doing in New Plants," Journal of Political Economy, 101(4), 561-583.

Bhutta, M.S. (2000) Engineering Subcontracting and Enterprise Development in Pakistan. Doctoral Thesis, Bahauddin Zakariya University (BZU), Multan, Pakistan. Boomgard, James J., James Kern, Calvin Miller, and Richard H. Patten (1992) "A Review of the Prospects for Rural Financial Institution Development in Bolivia," GEMINI Technical Report No. 31, Development Alternatives, Inc.Bethes da,Maryland.

Brenner, T. (2004) Local Industrial Clusters: Existence, Emergence, and Evolution, London: Routledge.

Bromley, R. (1978) "Introduction- The Urban Informal Sector. Why Is It Worth Discussing?" World Development, 6(9/10), 1033-1039.

Chari, S. (2000) "The Agrarian Origins of the Knitwear Industrial Cluster in Triuppur, India," World Development, 28(3), 579-599.

Dasanayaka, S.W.S.B (2009), “The Development of Informal Sector Small and Medium Scale Enterprises through Formation of Cluster and Networking. A Case Study based on Sri Lanka and Pakistan”, Business Review 4(2),107-122

David, C.C., and Otsuka, K. (1994) Modern Rice Technology and Income Distribution in Asia, Boulder: Lynne Reinner.

Eatwell, J., Milgate, M. and Newman, P. (ed.) 1987. The New Palgrave: A Dictionary of Economics, Vol.2 (E to J), London: Macmillan.

Evans, David S. (1987) “Test of Alternative Theories of Firm Growth," Journal of Political Economy, 95 (4), 657-674.

Federal Bureau of Statistics, FBS (2005) “Economic Census of Pakistan,” FBS, Islamabad. 
Feldman, M. P. (1994) "Knowledge Complementarily and Innovation," Small Business Economics, 6, 363-372.

Glaeser, E. L., Kalla, H.D., Scheinkman, J.A., and Shleifer, A. (1992) “Growth in Cities," Journal of Political Economy, 100(6), 1126-1152.

Hall, B. H. (1987) "The Relationship between Firm Size and Firm Growth in the U.S. Manufacturing Sector" Journal of Industrial Economics, 35(4), 583-606.

Hayami, Yujiro (ed.), 1998. Toward the Rural-Based Development of Commerce and Industry: Selected Experiences from East Asia, Washington, DC: World Bank Economic Development Institute.

Hayami, Y., Kikuchi, M., and B. Marchiano, E. (1998) "Structure of Rural-Based Industrialization: Metal Craft Manufacturing on the Outskirts of Greater Manila, the Philippines," Developing Economics, 36 (2), 132-54.

Henderson, J. V., Shalizi, Z., and Venables, A. J. (2001) "Geography and Development," Journal of Economic Geography, 1, 81-105.

Humphrey, John, and Schmitz, Hubert (1996) "The Triple C Approach to Local Industrial Policy," World Development 24, 1859-1877.

Irwin, D. A., and Klenow, P. J. (1994) "Learning-by-Doing Spillovers in the Semiconductor Industry," Journal of Political Economy, 102 (6), 1200-1227.

Jaffe, A. M., Trajtenberg, and Henderson, R. (1993) "Geographic Localization of Knowledge Spillovers as Evidenced by Patent Citations," Quarterly Journal of Economics, 108, 577-598.

Jovanovic, B. (1982) “Selection and the Evolution of Industry," Econometrica, 50(3), 649670 .

Kemal, A. R. (1993) "Why Do Small Firms Fail to Graduate to Medium and Large Firms in Pakistan” Pakistan Development Review, 32(4), 1249-57.

Knorringa, P. (1999) "Agra: An Old Cluster Facing the New Competition," World Development, 27(9), 1587-1604.

Krugman, P. (1991) Geography and Trade, Cambridge, MA: Massachusetts Institute of Technology Press.

Levy, B. (1991) "Transaction Costs, the Size of Firms and Industrial Policy," Journal of Development Studies, 34, 151-178.

Lotti, F., Santarelli, E., and Vivarelli, M. (1999) "Does Gibrat's Law Hold in the Case of Young, Small Firms?" Paper presented at the 40th Annual SIE conference, Ancona (29-30 October, 1999).

Lucas, R. E. Jr (1988) "On the Mechanics of Economic Development," Journal 
of monetary Economics, 22 (1), 3-42.

Lucas, R. E. Jr (1993) “Making a Miracle,” Econometrica, 61 (2), 251-272.

Majid, N., Kemal, A. R., Irfan, M., Mehmood, M., and Chaudhry, G. (2000) "Pakistan: Employment, Output and Productivity," Is sues in Development Discussion Paper No. 33, International Labor Organization (ILO), Geneva.

Mano, Y., and Otsuka, K. (2000) "Agglomeration Economies and Geographical Concentration of Industries: A Case Study of Manufacturing Sectors in Japan," Journal of the Japanese and International Economics, 14, 189-203.

Marshall, A. (1920) Principles of Economics: An Introductory Volume, London: Macmillan.

McCormick, D. (1999) “African Enterprise Clusters and Industrialization: Theory and Reality," World Development, 27 (9), 1531-1551.

McPherson, M. A. (1996) "Growth of Micro and Small Enterprises in Southern Africa," Journal of Development Economics, 48(2), 253-277.

Mead, D.C. (1994) “The Contribution of Small Enterprises to Employment Growth in Southern and Eastern Africa,” World Development, 22(12), 1881-1894.

Mead, D. C., and C. Liedholm (1998) "The Dynamics of Micro and Small Enterprises in Developing Countries," World Development, 26(1), 61 - 74.

Meyer-Stamer, J. (1998) "Path Dependence in Regional Development: Persistence and Change in Three Industrial Clusters in Santa Catalina/Brazil," World Development, 26(8), 1495-1511.

Mustafa, Iqbal., and Farrukh M. Khan (2005) "Small and Medium Enterprises in Pakistan," South A sian Journal, 9(July-September).

Nadvi, K., and Schmitz, H. (1994) "Industrial Clusters in Less Developed Countries: Review of Experiences and Research Agenda," IDS Discussion Paper 339, Institute of Development Studies, University of Sussex, Brighton.

Nadvi, K. (1999a) "The Cutting Edge: Collective Efficiency and International Competitiveness in Pakistan," Oxford Development Studies, 27(1), 81-107.

Nam, V. H., T. Sonobe, and K. Otsuka (2009) "An Inquiry into the Transformation Process of Village-based Industrial Clusters: The Case of an Iron and Steel Cluster in Northern Vietnam," Journal of Comparative Economics, 37 (4), 568-581.

Nam, V. H., T. Sonobe and K. Otsuka (2010) "An Inquiry into the Development Process of Village Industries: The Case of a Knitwear Cluster in Northern Vietnam," Journal of Development Studies, 46(2), 312-330.

Otsuka, Keijiro (2006). "Cluster-Based Industrial Development: A View from East Asia." Japanese Economic Review, 57 (3), 361-376. 
Pagano, P., and Schivardi, F. (2000) "Firm Size and Distribution Growth," Bank of Italy, Research Department.

Piero, M. (2004) "Industrial Clusters, Knowledge Integration and Performance," World Development, 32(2), 305-326.

Porter, M. (1990) The Competitive Advantage of Nations, New York: The Free Press.

Porter, M. (1998) "Clusters and the New Economics of Competition," Harvard Business Review, 76(6), 77-90.

Rabellotti, R. (1995) "Is There an "Industrial District Model?" Footwear Districts in Italy and Mexico Compared," World Development, 23 (1), 29-41.

Rabellotti, R. (1997) External Economies and Cooperation in Industrial Districts: A Comparison of Italy and Mexico, London: Macmillan.

Rabellotti, R. (1999) "Recovery of Mexican Cluster: Devaluation Bonanza or Collective Efficiency," World Development, 27 (9), 1571-1585.

Romer, P. M. (1986) "Increasing Returns and Long Run Growth," Journal of Political Economy, 94 (5), 1002-1037.

Romer, P. M. (1989) "Human Capital and Growth: Theory and Evidence," Working Paper No. 3173. National Bureau of Economic Research, Cambridge.

Roomi, M. A., and Hussain, S. T. (1998) "SMEs in Pakistan: A Survey of their Problems and Prospects," Konrad Adenauer Foundation Working Papers Series. Lahore University of Management Sciences (LUMS), Lahore.

Rosenfeld, S. A. (1995) Industrial Strength Strategies: Regional Business Cluster and Public Policy, Washington, DC. The Aspen Institute.

Schmitz, H. (1995b) "Collective Efficiency: Growth Path for Small Scale Industry," Journal of Development Studies, 31(4). 529-566.

Schmitz, H. (1999b) "Global Competition and Local Cooperation: Success and Failure in the Sinos Valley, Brazil,” World Development, 27 (9), 1627-1650.

Schmitz H and Musyck B (1994) 'Industrial Districts in Europe: Policy Lessons for Developing Countries?', World Development, 22 (6), 889-910

Schmitz, H., and Nadvi, K. (1999) "Clustering and Industrialization: Introduction," World Development, 27(9), 1503-1514.

Schumpeter, J. A. (1912) The Theory of Economic Development, New York: Oxford University Press.

Small and Medium Enterprises Development Authority, SMEDA (2005) "Cluster Profile of Electrical Fittings Industry in Sargodha," SMEDA, Lahore. 
Sonobe, T., and Briones, R.M. (2001) “The Role of Urban-Rural Subcontracting in Rural Industrialization: A Case Study of the Export-oriented Garment and Metal Craft Industries in the Philippines," Tokyo Metropolitan University, Faculty of Economics, Unpublished Manuscript.

Sonobe, T., and Otsuka, K. (2006) Cluster-Based Industrial Development: An East Asian Model, Basingstoke: Palgrave Macmillan.

Sonobe,T., Aketon., J. E., and Otsuka, K. (2009) “An Exploration into the Successful Development of the Leather-Shoe Industry in Ethiopia," Review of Development Economics, 13(4), 719-736.

Sonobe, T., Hu, D., and Otsuka, K. (2002) "Process of Cluster Formation in China: A Case Study of a Garment Town," Journal of Development Studies, 39 (1), 118-139.

Sonobe, T., Hu, D., and Otsuka, K. (2004) "From Inferior to Superior Products: An Inquiry into the Wenzhou Model of Industrial Development in China". Journal of Comparative Economics, 32 (3), 542-563.

Sonobe, T., Kawakami, M., and Otsuka, K. (2003) "Changing Roles of Innovation and Imitation in Industrial Development: The Case of the Machine Tool Industry in Taiwan," Economic Development and Cultural Change, 52 (1), 103-128.

Swann, P., and Prevezer, M. (1996) "A Comparison of the Dynamics of Industrial Clustering in Computing and Biotechnology," Research Policy, 25, 1139-1157.

Tewari, M. (1999) "Successful Adjustment in Indian Industry: the Case of Ludhiana's Woolen Knitwear Cluster,” World Development, 27 (9), 1651-1671.

Weijland, H. (1999) "Micro-Enterprises Clusters in Rural Indonesia: Industrial Seedbed and Policy Target," World Development, 27(9), 1515-1530.

Yamamura, E., Sonobe, T., and Otsuka, K. (2003) "Human Capital, Cluster formation, and International Relocation: the Case of Garment Industry in Japan, 1968-98," Journal of Economic Geography, 3 (1), 37-56.

Yamamura, E., Sonobe, T., and Otsuka, K. (2005) "Time Paths in Innovation, Imitation, and Growth: The Case of the Motorcycle Industry in Postwar Japan," Journal of Evolutionary Economics, 15(2), 164-186.

Young, A. (1993) "Inventions and Bounded Learning by Doing," Journal of Political Economy, 101(3), 443-472.

Don't 'manage' culture, celebrate it as source of different ideas.

Ashok Soota, President of Wypro (1984-1999) 